\title{
Abundance, seed pod nutritional characteristics, and seed germination of leguminous trees in South Kordofan, Sudan
}

\author{
IBRAHIM M. HASHIM
}

\begin{abstract}
Seed pods of leguminous trees are a potential source of livestock feed in Sudan. Abundance, seed pod nutritional characteristics, and seed germination of leguminous trees in south Kordofan were examined. In the study area, densities of all trees and leguminous trees were 99.8 and $\mathbf{2 4 . 0}$ trees/ha, respectively. Percentages of crude protein in seed pods, after seeds were removed, ranged from 0.1 to 27.2 , in vitro dry matter digestibility from 28.1 to 59.8 , in vitro organic matter digestibility from 23.3 to 59.9 , and neutraldetergent fiber from $\mathbf{5 0 . 8}$ to $\mathbf{7 9 . 3}$ during the dry season.

Seeds of sunut (A cacia nilotica) and girfaldud (Abizia anthelmintica) germinated only after soaking in a large volume of water; they may have contained chemical inhibitors that restricted germination. Undamaged seeds of other tree species required scarification with concentrated sulphuric acid for 5 to 150 minutes to give optimum germination in 2 to 9 days. Seeds damaged by Bruchid beetles failed to germinate if their embryos were enten, but germination of damaged seeds whose embryos were not eaten was sometimes as high as that of the controls. Bores made by the Bruchids in seeds may have facilitated moisture imbibition.
\end{abstract}

Key Words: leguminous trees, abundance, seed pods, nutritional characteristics, seed germination

Leguminous trees provide shade, cover, and forage for animals in savanna vegetation in Sudan. Forage produced consisted of leaves, flowers, and seed pods rich in proteins, vitamins, and minerals (National Research Council 1979). The seed pods are eaten by domestic livestock and wildlife (Jarman 1967; Lamprey et al. 1974; Gwynne 1979; Owen-Smith and Cooper 1983; Hashim 1984, 1988).

Because leguminous trees produce seed pods during the dry season when forage quantity and quality are generally low, information about ecology of the trees and quality of their seed pods is needed. The first objective of this study was to evaluate abundance and seed pod nutritional characteristics of common leguminous trees, including talh, saljam, umsinaina, laot, kuk, sunut, haraz, druba, arad, siraira, girfaldud, kulkul, abanus, kadad, kharroub, and abussurug (see Table 1 for scientific names). The second objective was to study germination of seeds from these trees.

\section{Materials and Methods}

\section{Study Area}

This study was conducted at the Kadugli Research Station in south Kordofan, Sudan. South Kordofan lies within the savanna zone of the Sahelian belt and can be classified as having hot, semiarid climate. March is the hottest month at Kadugli with a maximum of $41^{\circ} \mathrm{C}$ and a minimum of $24^{\circ} \mathrm{C}$. December and January are the coolest months with a maximum of $35^{\circ} \mathrm{C}$ and a minimum of $18^{\circ} \mathrm{C}$. Rainfall varies from about $500 \mathrm{~mm} / \mathrm{yr}$ in the north to over $800 \mathrm{~mm}$ in the south. Rains occur in a single season, primarily from June to September, although there is some rainfall in May and October. A short, hot season occurs in October and

\footnotetext{
Author is a range scientist for the Agricultural Research Corporation, Western Sudan Agricultural Research Project, P.O. Box 10, Kadugli, Sudan. Manuscript accepted 12 December 1989.
}

November after the rains, followed by a cool, dry season from December to February. The main hot season occurs from March to May. A complete description of soils and vegetation is given by Bunderson et al. (1984).

\section{Density}

Density of leguminous trees was determined by the nearest neighbor method (Clark and Evans 1954). Four random points were located in a stand, and a line transect $1 \mathrm{~km}$ long was run in a random direction from each point. At points $50 \mathrm{~m}$ apart along each transect, the tree nearest to each point and the tree nearest to it (the nearest neighbor) were identified. The distance between the tree nearest to each point and its nearest neighbor was measured with a steel tape. If the same tree was the nearest tree to 2 different points, as sometimes happened in sparse stands, its nearest neighbor was recorded only once. About $25 \mathrm{~km}$ of line transects were sampled on different soil types; a total of 1,037 trees were encountered. Density (D) was calculated for all tree species by the following equation:

$$
D(\text { tree } / \text { ha })=10,000 /(1.67 \mathrm{X})
$$

where $X$ is the mean distance to the nearest tree and 1.67 is a correction factor.

\section{Nutritional Characteristics of Seed Pods}

Seed pods of leguminous trees encountered during the sampling were collected immediately after they matured between December 1986 and February 1987. Seeds were removed from seed pods and were stored in metal containers at room temperature varying between $28^{\circ} \mathrm{C}$ and $39^{\circ} \mathrm{C}$ for germination studies, whereas the empty seed pods were oven-dried and ground in a Wiley mill to pass through 1-mm mesh.

Nitrogen content of seed pods was determined by the standard Kjeldahl N procedure. Neutral-detergent fiber was determined according to the method described by Van Soest (1982). Determination of IVDMD followed the procedure developed by Tilley and Terry (1963), IVOMD the method of AOAC (1984). Three samples of seed pods from each species were analyzed. Values were accepted when the coefficient of variability was less than or equal to $2 \%$ for crude protein and in vitro digestibility and $3 \%$ for NDF; if values were larger, the analyses were repeated (Galyean 1980).

\section{Germination Trials}

Pilot germination trials showed that only soaking in concentrated $\mathrm{H}_{2} \mathrm{SO}_{4}$ or soaking in large volumes of water (sunut and girfaldud only) increased percentages of seed germination. Boiling in water for 5 minutes, heating in sand at $60^{\circ} \mathrm{C}$ for 30 hours, or in vitro digestion had no effect.

In the trials reported here, intact seeds of girfaldud were soaked in 2 liters of distilled water for 12 hours; those of sunut were soaked in water for 24 hours, followed by scarification in concentrated $\mathrm{H}_{2} \mathrm{SO}_{4}$ for 10 minutes. Intact seeds of other species were scarified in concentrated $\mathrm{H}_{2} \mathrm{SO}_{4}$ for as long as necessary to produce maximum germination (5 to 150 minutes) as determined in the pilot trials. Seeds were then removed from the acid and thoroughly washed in tap water before subjecting them to germination. Damaged seeds were germinated without pretreatment. 
Table 1. Nutritional characteristics of seed pods from leguminous trees in south Kordofan, Sudan, December 1986 to February 1987.

\begin{tabular}{|c|c|c|c|c|c|}
\hline \multicolumn{2}{|l|}{ Tree species name } & \multirow{2}{*}{$\begin{array}{c}\text { Crude } \\
\text { protein }\end{array}$} & \multirow{2}{*}{$\begin{array}{l}\text { In vitro } \\
\text { dry matter } \\
\text { digesti- } \\
\text { bility }\end{array}$} & \multirow{2}{*}{$\begin{array}{c}\text { In vitro } \\
\text { organic } \\
\text { matter } \\
\text { digestibility }\end{array}$} & \multirow{2}{*}{$\begin{array}{l}\text { Neutral } \\
\text { detergent } \\
\text { fiber }\end{array}$} \\
\hline Scientific & Common & & & & \\
\hline & & - & - & - & $\ldots \ldots$ \\
\hline Acacia seyal & Talh & 27.2 & 41.3 & 39.0 & 78.5 \\
\hline Acacia gerrardii & Saljam & 16.6 & 30.3 & 33.0 & 76.7 \\
\hline Acacia polyacantha & Umsinaina & 7.0 & 34.0 & 30.1 & 76.0 \\
\hline Acacia nubica & Laot & 9.1 & 35.8 & 33.4 & 77.3 \\
\hline Acacia sieberiana & Kuk & 9.0 & 43.9 & 45.8 & 59.2 \\
\hline Acacia nilotica & Sunut & 0.1 & 56.7 & 54.9 & 51.9 \\
\hline Acacia albida & Haraz & 16.5 & 59.8 & 59.9 & 59.2 \\
\hline Albizia lebbeck & Druba & 27.7 & 28.3 & 31.1 & 79.3 \\
\hline Albizia amara & Arad & 0.3 & 28.1 & 28.1 & 78.8 \\
\hline Albizia aylmeri & Siraira & 4.5 & 36.6 & 23.3 & 73.7 \\
\hline Albizia anthelmintica & Girfaldud & 9.2 & 36.3 & 33.1 & 74.3 \\
\hline Bauhinia rufescens & Kulkul & 4.2 & 32.0 & 29.0 & 75.0 \\
\hline Dalbergia melanoxylon & Abanus & 12.1 & 34.7 & 37.1 & 71.1 \\
\hline Dichrostachys cinerea & Kadad & 10.9 & 50.5 & 48.1 & 53.1 \\
\hline Piliostigma reticulatum & Kharroub & 4.2 & 38.5 & 36.1 & 68.1 \\
\hline Prosopis africana & Abussurug & 9.2 & 48.2 & 48.6 & 50.8 \\
\hline
\end{tabular}

Experimental units were 3 replications of 10 seeds, each placed on 2 moistened filter papers in a $10-\mathrm{cm}$ diameter petri dish. The dishes were located randomly in a laboratory at room temperature. Germination trials were continued for 14 days. Seeds were considered germinated if they produced a 2-mm long radicle (Everitt 1983). Values for percentage of germination were accepted when the coefficient of variability was less than or equal to $2 \%$.

\section{Results and Discussion}

\section{Density}

Talh, arad, and kharroub were the most abundant trees; densities were $7.04,5.59$, and 4.53 trees/ha, respectively. Saljam, unsinaina, laot, abanus, kuk, and abssurug were less abundant, at 0.87 . $0.87,0.29,0.19,0.29$, and 0.18 trees/ ha. Sunut, haraz, siraira and girfaldud were restricted to riparian zones, and druba, kadad and kulkul to sandy soils.

\section{Nutritional Characteristics of Seed Pods}

Seed pods of most leguminous trees showed relatively high percentages of crude protein (CP), in vitro dry matter digestibility
(IVDMD), in vitro organic matter digestibility (IVOMD), and neutral detergent fiber (NDF) (Table 1). Percentages of $\mathrm{CP}$ ranged from 0.1 to 27.7 ; the median was 9.1. Seed hulls showing $\mathbf{C P}$ concentrations higher than the median were those of talh, saljam, haraz, druba, girfaldud, abanus, kadad, and abussurug. Crude protein concentrations in sunut and arad pods were extremely low, 0.1 and $0.3 \%$, respectively, or less than the CP concentration of sawdust, reported as 0.4 to $0.6 \%$ by Allison et al. (1963).

In vitro dry matter digestibility of seed pods ranged from 28.1 to $59.9 \%$, and IVOMD from 23.3 to $59.9 \%$; medians were $36.4 \%$ for IVDMD and 34.6\% for IVOMD. Talh, kuk, sunut, haraz, kadad, kharroub, and abussurug consistently showed IVDMD and IVOMD higher than the medians. Digestibility of sunut pods was high in spite of very low CP content.

Neutral-detergent fiber ranged from 50.8 to $79.3 \%$; the median was $74.0 \%$. Trees producing seed pods showing NDF lower than the median include kuk, sunut, haraz, siraira, abanus, kadad, kharroub, and abussurug. Seed pods of haraz, kadad, and abussurug consistently showed CP, IVDMD, IVOMD higher than, but NDF lower than, the medians.

Table 2. Germination of intact leguminous tree seeds and seeds scarified with concentrated sulfuric acid or damaged by Bruchid beetles.

\begin{tabular}{|c|c|c|c|c|c|c|c|}
\hline \multirow[b]{2}{*}{ Tree species } & \multirow[b]{2}{*}{$\begin{array}{l}\text { Scarification } \\
\text { time, min }\end{array}$} & \multicolumn{3}{|c|}{ ___Percent germination-___ } & \multicolumn{3}{|c|}{-Days to germinate- } \\
\hline & & Intact & Scarified & $\begin{array}{c}\text { Beetle- } \\
\text { damaged }\end{array}$ & Intact & Scarified & $\begin{array}{l}\text { Beetle- } \\
\text { damaged }\end{array}$ \\
\hline Talh & 25 & 10 & 100 & $\ldots$ & 4 & 4 & - \\
\hline Saljam & 25 & 4 & 100 & 13 & 12 & 2 & 4 \\
\hline Umsinaina & 30 & $\mathbf{0}$ & 90 & $\mathbf{0}$ & - - & 2 & - \\
\hline Laot & 150 & $\mathbf{0}$ & 62 & 0 & -— & 8 & $\longrightarrow$ \\
\hline Kuk & 5 & 23 & 80 & 0 & 11 & 8 & - \\
\hline Sunut ${ }^{1}$ & 10 & 0 & 50 & - - & 0 & 9 & - \\
\hline Haraz & 5 & 46 & 100 & 3 & 11 & 4 & 3 \\
\hline Druba & 10 & 0 & 50 & 0 & - & 4 & - \\
\hline Arad & 20 & 0 & 100 & 0 & - & 2 & - \\
\hline Siraira & 10 & 0 & 60 & - & - & 2 & - - \\
\hline Girfaldud 2 & 0 & 0 & 80 & - - & 10 & 2 & - \\
\hline Kulkul & 15 & 10 & 70 & - & 9 & 5 & - \\
\hline Abanus & - & 93 & - & - & 13 & - - & - \\
\hline Kadad & 20 & 20 & 100 & 0 & - & 5 & - \\
\hline Kharroub & 10 & 0 & 40 & 20 & 10 & 7 & 6 \\
\hline Abussurug & 5 & 7 & 70 & 7 & & 8 & 6 \\
\hline
\end{tabular}

'Soaked in distilled water for 24 hours, followed by acid scarification.

2Soaked in distilled water for 12 hours. 


\section{Germination}

Scarification of undamaged seeds in concentrated $\mathrm{H}_{2} \mathrm{SO}_{4}$ increased germination above that of the controls (Table 2). Girfaldud and sunut seeds, however, germinated best when soaked in distilled water, followed by acid scarification for the latter species. Seeds of abanus, on the other hand, did not require any treatment for satisfactory germination.

Germination of seeds damaged by Bruchid borers (Table 2) was similar to that of the undamaged seeds in the control, and the days to germinate were similar to those of the acid scarified seeds, with a few exceptions. Girfaldud seeds took longer to germinate when beetle damaged; fewer kuk, haraz, and kadad seeds germinated after beetle damage. No damaged seeds of umsinaina, laot, kuk, sunut, druba, arad, and kadad germinated.

\section{Management Implications}

Because of relatively high nutritive value, seed pods of haraz, kadad, and abussurug are suitable supplements for livestock during the dry season, extending from late February to July, when forage quantity and quality become limiting (Hashim and Fadlalla 1989). In a feeding trial, Hashim (1988) supplemented sheep with seed pods of haraz and kadad during the dry season and found that sheep supplemented gained more liveweight than the control, and sheep supplemented with haraz gained more liveweight than sheep supplemented with kadad.

Haraz, kadad and abussurug are not common trees in south Kordofan; haraz and kadad are restricted to riprian and sandy sites, respectively. A higher percentage of seed from all 3 species germinated when properly scarified with acid. These species can and should be propagated to improve diet quality of animals during the dry season. In addition, these trees could be used as windbreaks and for watershed management. Abussurug produces high quality wood.

\section{Literature Cited}

AOAC. 1984. Official methods of analysis (13th ed.) Assoc. of Off. Anal. Chem., Washington, D.C.

Altison, F.E., R.M. Murphy, and C.J. Klein. 1963. The nitrogen requirements for the decomposition of various kinds of finely-ground woods in soils. Soil Sci. 96:187-190.

Bunderson, W.T., R.H. Cook, and B. Fadlalla. 1984. Range/Livestock research activities 1982/1983. WSARP Pub. 29. Khartoum, Sudan, and Pullman, Wash.

Clark, P.J., and F.C. Evans. 1954. Distance to nearest neighbor as a measure of spatial relationships in population. Ecol. 35:445-453.

Everitt, J.H. 1983. Seed germination characteristics of three woody plant species from south Texas. J. Range Manage. 36:41 1-414.

Galyean, M. 1980. Techniques and procedures in animal nutrition research. Dep. Animal Science, New Mexico State Univ., Las Cruces.

Gwynne, M.D. 1969. The nutritive value of Acacia pods in relation to Acacia seed digestibility by ungulates. E. Afr. Wildl. J. 7:176-178.

Hashim, I.M. 1984. Meadow use by wild ungulates in Dinder National Park, Sudan. Ph.D. Thesis. N.M. State Univ., Las Cruces.

Hashim, I.M. 1988. Liveweight change in sheep supplemented with seed pods of two leguminous trees in south Kordofan, Sudan. A paper presented at PANESA/ARNAB joint workshop on Utilization of Research in Forages and Agricultural By-products, 5-9 December. Lilongwe, Malawi.

Hashim, I.M. and B. Fadlalla. 1989. Observation on cattle liveweight changes and fecal indices in Sudan. J. Range Manage. 42:163-165.

Jarman, P.J. 1967. Damage of Acacia tortillis seeds eaten by impala. E. Afr. Wildl. J. 14:223-225.

Lamprey, H.F., G. Halvey, and S. Makacha. 1974. Interaction between Acacia, Bruchid seed beetles and large herbivores. E. Afr. Wildl. J. 12:81-85.

National Research Council. 1979. Tropical legumes: resources of the future. Nat. Acad. Sci., Wash., D.C.

Owen-Smith, N., and S.M. Cooper. 1983. Aspect of feeding ecology of a browsing ruminant: the kudu. S. Afr. J. Anim. Sci. 13:35-38.

Tilley, J.M.A., and R.A. Terry. 1963. A two-stage technique for in vitro digestion of forage crops. J. Br. Grassl. Soc. 18:104-111.

Van Soest, P.J. 1982. Nutritional ecology of the ruminants. O\&B Book Inc., Corvallis, Oregon.

\section{Moving?}

If you are changing your address, notifying the post office is not sufficient to keep your journal coming on time. Please send your new address and the label with your old address to the Society for Range Management, 1839 York Street, Denver, Colorado 80206, USA. 